\title{
Die plek van Empedokles in die metafisies-mistieke tradisie
}

\author{
J S Krüger \\ Emeritus Professor en Navorsingsgenoot \\ Departement Godsdienswetenskap en Arabies \\ Universiteit van Suid-Afrika
}

\begin{abstract}
The place of Empedocles in metaphysical-mystical tradition

This article argues that Empedocles was more than a pre-Socratic philosopher. His thinking was also essentially mystical and should be situated on a large map of metaphysical-mystical continuities with the following dimensions: A historically discernable cultural and religious pool, encompassing not only South-Eastern Europe, Asia Minor and Mediterranean Africa, but also the north-eastern Eurasian shamanic tradition, and India; an historically largely inaccesible esoteric tradition; a set of structural elements of the human psyche, running under and across historical religions through time; and the development of a new convergence of previously historically unconnected mystical traditions in the social and cultural circumstances of today. In particular, the article investigates similarities and differences between Empedocles and Indian (specifically Buddhist) views on various issues, such as the four roots and the cyclical dialectic of love and strife. In that context the article notes the remarkable interpretation of Empedocles by Peter Kingsley which seems to draw Empedocles closer to Buddhism, but without explicating this implication of his reception.
\end{abstract}

\section{PROBLEEM EN BENADERING}

Die beskikbare historiese en anekdotiese getuienis aangaande die voorSokratiese digter-denker Empedokles plaas hom in die Magna Graecia van die eerste twee derdes van die vyfde eeu VHJ (c494 -c434), spesifiek in die Siciliaanse stad Akragas (die huidige Agrigento). Vanuit hierdie stad het hy as flambojante, charismatiese leermeester en rondreisende wonderwerker opgetree en roem onder sy tydgenote verwerf - in so 'n mate dat hy deur sy volgelinge as goddelik beskou is. 
Die probleem wat in hierdie artikel in 'n godsdienswetenskaplike (spesifiek: mistiek-historiese en mistiek-vergelykende) raam behandel word, sentreer in die plek van Empedokles in die groter metafisies-mistieke tradisie.

"Plek" in die titel hierbo verwys na twee onderskeibare perspektiewe wat nietemin aan mekaar gekoppel kan word: 'n historiese en 'n sistematiese. Die eerste het betrekking op ' $n$ persoon of stel denkbeelde se gesitueerdheid in 'n proses van aanwysbare historiese kontinuïteite en beïnvloedings; die tweede op die konstruksie van 'n teoretiese sintese waarin histories weinigverwante of selfs onverwante persone of stelle denkbeelde in saaklike verband met mekaar gebring word. So 'n koppeling van die historiese en die sistematiese word in hierdie artikel bewerkstellig.

"Metafisiese mistiek" (wat, soos al dergelike begripsomskrywings, 'n half-willekeurige en relatiewe karakter het) verwys na 'n denkwyse waarin daar (soos in die filosofie en teologie) na die uiteindelike wese van kosmos, natuur en mens (en selfs God) gevra word. Hier gebeur dit egter nie (soos in die hoofstroom akademiese filosofie) op slegs redelike gronde nie en ook nie (soos in die hoofstroom tradisionele teologie) op bonatuurlike openbaringsgronde nie, maar op grond van persoonlike ervaring, intuïtiewe deelname en mities-poëtiese verbeelding. Hierdie begrip sou byvoorbeeld nie op Aristoteles en Karl Barth van toepassing wees nie; op Plato wel. In die buurt van die begrip "mistiek" lê die begrippe "alchemie", "magie" en "esoterika" (Krüger 2006:9-17).

In hierdie artikel laat die begrip "tradisie" verskillende skakerings toe, wisselend tussen en ook as kombinasies van die volgende breë moontlikhede:

a) 'n histories aanwysbare gemeenskaplike religieus-kulturele poel oor 'n sekere tydperk (byvoorbeeld die Joodse of Christelike tradisie; of die kultureel-religieuse kontinent in die eeue voor en na die begin van die huidige jaartelling wat dele van Suid-Oos-Europa, Klein-Asië en Mediterreense Afrika (Egipte) ingesluit het en waarin gedeelde gedagtes vryelik heen en weer gevloei het);

b) 'n werklik-bestaande maar vir die historiese navorsing grotendeels verborge ondergrondse esoteriese tradisie, waarskynlik deur 'n proses van inisiasie oorgelewer (bv die Pythagorese tradisie);

c) in 'n losser sin, 'n stel struktuurelemente wat deur en oor historiese religieë loop en deur soortgelyke sosiale omstandighede geaktiveer 
kan word, maar sonder noodwendige direkte historiese beïnvloeding (byvoorbeeld die sjamanisme).

d) in 'n nog losser maar tog verbandhoudende sin: die teoretiese koppeling van twee of meer kontekste en sodoende die daarstelling van 'n tradisie, 'n stuk gemeenskaplikheid, wat tevore nie daar was nie of altans nie raakgesien is nie.

Indien nie een van die vier breë moontlikhede op die verhouding tussen Empedokles en byvoorbeeld die Boeddhisme van toepassing sou wees nie, sou ons met die vasstel van blote toevallige ooreenkomste tevrede moet wees. Maar dit sou as 'n onbevredigende gevolgtrekking beskou moet word. Wat die plek van Empedokles betref, is die strekking van hierdie artikel om faktore (a), (b) en (c) streng in ag te neem - maar om ook met omsigtigheid in die rigting van (d) te beweeg, in die besef dat die mensheid vandag 'n onomkeerbare epog van kulturele, religieuse en mistieke konvergensie binnegegaan het.

Die vraag is dus: waar pas Empedokles in die groter historiese kompleks van die metafisiese mistiek in, en wat is sy betekenis in daardie kompleks? Hierdie vrae sal benader word op grond van die fragmente van Empedokles soos oorgelewer in sy twee gedigte Peri physeos (Aangaande die natuur) en Katharmoi (Reinigings), soos deur Diels (1992:276-374) ${ }^{1}$ georden. Alhoewel 'n groot aantal werke oor uiteenlopende temas aan Empedokles toegeskryf is, berus sy reputasie op slegs hierdie twee stelle fragmente (ongeveer 450 reëls). Dit is nie bekend in welke volgorde hierdie twee gedigte ontstaan het nie. Wat wel vas staan, is dat die eerste (esoteriese gedig) gerig was aan die enkeling, die dissipel Pausanias, en die tweede (eksoteriese, publieke gedig) aan sy stadsgenote in Akragas. Die twee gedigte vul mekaar aan, en bied saam genoeg om Empedokles se metafisiese mistiek met 'n groot mate van waarskynlikheid te rekonstrueer. So 'n onderneming, ofskoon nie haglik onuitvoerbaar nie, bly nietemin tergend onfinaliseerbaar. Daar het genoeg onsekerhede oorgebly om deur die eeue 'n onoorsienbare massa interpretasies (wat nie naastenby volledig in 'n artikel gereflekteer kan word nie) te kon stimuleer.

Naas die historiese benadering, berustend op die beskikbare primêre bronne en geselekteerde sekondêre interpretasies, sal hier tweedens gebruik gemaak word van 'n vergelykende benadering, bewus van die riskante kante aan enige vergelykende projek. Derdens sal die artikel tendens-

\footnotetext{
${ }^{1}$ Alle aanhalings uit Empedokles se gedigte hieronder verwys na die betrokke fragment (afgekort as "fr") uit die rekonstruksie van Diels (1992).
} 
ekstrapolerend werk, wat verwys na 'n benadering waar twee of meer stelsels gebruik word om mekaar te reflekteer en te verhelder, en waar gepoog word om hulle na mekaar toe te trek in 'n groter sintetiese verband.

\section{REKONSTRUKSIE VAN DIE LEER VAN EMPEDOKLES}

\subsection{Weet en nie-weet}

Vir Empedokles verkeer die gewone mens in 'n staat van verdwaasde onkunde in 'n illusionêre werklikheid. Vasgevang in hulle beperkte sintuiglike ervaring, neem mense tydens hulle kort leeftye weinig waar, maar totaliseer hulle fragmentariese ervarings tot die illusie dat hulle die geheel (to holon) gevind het ( $\mathrm{fr} 2$ ). Tog is die waarheid van dinge nie onbereikbaar nie. Sintuiglike ervaring en die rede het 'n relatiewe waarde, maar om ingelei (geïnisieer) te word in die ware insig (metis), is die begeleiding van 'n goddelike leermeester - soos Empedokles - nodig. Die ware insig is direkte ervaring wat deurstoot na die dimensie agter die illusie. Om hierdie doel te bereik, is dit nodig dat die leermeester die gewone ervarings- en dinkpatrone van die leerling deurbreek. "Werklikheid" en "wete" korreleer. In aansluiting by Empedokles se bipolêre ontologie (sien hieronder), is kennis en die weg tot kennis dialekties, gelaai met dubbelsinnigheid en kontradiksie. Die gedigte self is manifestasies van die weg tot insig. Hulle is nie didaktiese gedigte in die sin dat kennis direk en duidelik meegedeel word en kumulatief groei tot 'n totaalwete aangaande 'n totaalwerklikheid nie. Die digter-leermeester is woord-towenaar, oëverblinder, wat op een vlak die sintuiglike ervaring en alledaagse verstand bevestig, maar hulle op 'n dieper vlak ondermyn (Kingsley 2003:passim). Woorde en begrippe wat oënskynlik 'n objektiewe werklikheid registreer, word van binne af gesaboteer. Hy praat in raaisels, sluit by die gewone mens se ervarings en opvattings aan (byvoorbeeld dat liefde goed en twis sleg is, of dat daar 'n duidelike skeiding is tussen lewe en dood), maar terselfdertyd is hy met groot vaardigheid besig om die mens wat bereid is om te leer om aandagtig dieper te sien, in te lei in 'n dieper waarheid.

Die hoogste kennis is mistieke kennis waarin die leerling deel verkry aan die wete en bewustheid wat in alle dinge voorkom. Empedokles se formulerings van hoe daardie verinnerlikte onderrig verkry word anderkant die menigvuldige verstrooiings van die alledaagse lewe, laat inisiasie in 'n meditatiewe sisteem vermoed: 


\author{
As jy dit opneem in die kuil van jou maag \\ en deurgaans gunstig aandagtig betrag \\ sal dit alles jou lewenslank bybly \\ en sal jy nog veel meer wen \\ want dit groei na eie-aard diep in jou wese in. \\ Maar reik na die ander soort ding \\ wat mense gedurig aflei \\ en hul diep-dink verstomp - \\ dan verlaat hulle jou as jou tyd daar is \\ vol verlange om by hul eie soort tuis te kom. \\ Want alles - weet dit - het verstand en deel aan dink.
}

(fr 110)

\title{
2.2 Vier, twee, een: Die ewige kosmiese sirkelgang
}

Hoe sien Empedokles se ware werklikheid dus daaruit? Elke individuele ding wat bestaan, groot en klein en selfs "die lank-lewende gode" (fr 23), is 'n mengsel van vier elemente, deur Empedokles oer-wortels of risome (rizoma) genoem: lug [aither, ouranos), aarde [gaia, chton], vuur [pur, helios] en water [hudor, ombros, thalassa, pontos]. Hierdie strukturele boustene in die kosmos volgens Empedokles is sintuiglik in die natuur waarneembaar. Elk van hierdie elemente word doelbewus raaiselagtig maar tog ook konsekwent met 'n spesifieke godheid verbind: lug met Zeus, aarde met Hera, vuur met Aidoneus (Hades) en water met Nestis:

Hoor eers die vier wortels van alles wat is:

ligtende Zeus en lewe-gewende Hera,

Aidoneus en Nestis wie se trane sterflike strome laat vloei

(fr 6)

In hulle oorspronklike staat lê die vier oer-elemente los van mekaar, konsentries gerangskik. Aan die binnekant van die oer-staat is swaar aarde, dan vloeibare water, dan brandende vuur en dan, buite-om, ligte lug. Vanuit die moderne oogpunt is dit stellig heel primitiewe astronomie of chemie. Maar dan bring Empedokles 'n metafisiese beginsel in wat van die grootste betekenis is: die dialektiek van wat hy antropomorf-mitologies "liefde" (philotes) en "twis" (neikos) noem. Die motoriese dinamika wat die vier grondelemente aktiveer bestaan dus uit twee oerkragte wat op 'n hoër vlak van abstraksie as die grondelemente funksioneer, maar nogtans ook empiries ervaarbaar is. 
Hierdie sestal basiese begrippe is multivalent. Terminologies is hulle aan die alledaagse ervaring ontleen. Aan godsname gekoppel, verraai hulle ' $n$ mitologiese res. Met verwysing na wat later as "wetenskap" sou kristalliseer, moet hulle as baanbrekende begrippe beoordeel word. Hulle dien 'n redelike, filosofies-metafisiese doel. En hulle het 'n mistieke, selfs magies-esoteriese dimensie.

In die volgende samevattende sleutelfragment word Pausanias in die waarheid ingelei:

\author{
Tweeledig sal ek praat: \\ nou ontstaan een alleen uit veel \\ en dan ontwikkel veel uit een. \\ Dubbel is geboorte \\ van sterflike dinge \\ en dubbel die dood. \\ Want eenwording skep en vernietig \\ en skeiding bring voort en verdeel \\ in verandering sonder end: \\ nou word alles deur liefde een \\ en dan skei dit deur die haat van twis. \\ Vir sover een leer om uit veel te ontstaan \\ en veel uit die verdeelde een voortkom \\ word hulle \\ en hou nie stand nie \\ maar vir sover hul blywend verander \\ is hulle \\ in die ewige kring.
}

Luister na my woorde want begrip groei deur leer.

Die strekking van my leer het ek aangekondig.

Tweeledig sal ek praat:

nou ontstaan een alleen uit veel

en dan ontwikkel veel uit een:

vuur en water en aarde en lug se oneindige hoogte

en eenkant harde twis oral eweveel

en liefde ewewigtig lank en breed tussen hulle in

- aanskou haar met die gees

staar nie met die oë nie -

almal weet sy is ingebore in die lywe van sterflikes

en sy laat hulle mooi dinge dink

en lekker dinge saam doen

en hulle noem haar Vreugde en Aphrodite

maar hoe sy onder hulle dans het geen sterfling aanskou nie

maar jy-verneem die onbedrieglike gang van die rede. 
Die wortels is ewe sterk en oud elk met 'n eie funksie en aard heers beurtelings in die rondgang van tyd

niks kom by en niks gaan weg nie sou hul verdwyn sou daar niks meer wees nie wat sou die al vergroot en vanwaar sou dit kom? waarheen sou hul verdwyn want niks is van hul leeg nie? hulle is al wat is deurdring mekaar

word so verskillende dinge op verskillende tye maar bly self altyd dieselfde.

Dit is waarskynlik so dat hy om didaktiese redes sy vertrekpunt neem in die vier oer-wortels in hul geskeie staat, dit wil sê in 'n staat van volkome "twis". Op grond daarvan het sommige gemeen dat twis ook metafisiese voorrang by hom geniet. Die meeste (bv Nietzsche 2001:114-118; Kirk \& Raven 1966:327; Dreyer 1976:51) het met net soveel oortuiging beweer dat "liefde", die sfeer waarin harmonie en vrede heers, by hom die primaat het. Afgesien van welke een van die twee die vertrekpunt van sy denke sou wees, is hy op weinig uitsonderings na deur die geskiedenis geïnterpreteer as sou liefde ten minste die vanselfsprekende ideaal wees waarheen die kosmos en alles daarin sou neig. Die beste lees van Empedokles sal, meen ek, die twee beginsels van "twis"en "liefde" as ewe belangrik beskou. Hulle is in 'n ewige dialektiek met mekaar gewikkel, waarin albei generatief en destruktief is en geeneen van die twee die finale oorhand kry nie.

Sy kosmologie suggereer dat die oorspronklik-afsonderlike vier oerelemente geleidelik onder die invloed van "liefde", die drang tot integrasie, uit hul selfgenoegsame geskeidenheid beweeg word. Hulle begin middelpuntsoekend vermeng. Geleidelik kry liefde die oorhand. Die uiteinde hiervan is 'n staat van volkome vermenging van die vier, 'n staat van volkome liefde (harmonie):

\author{
volronde sfeer \\ oral aan sigself gelyk \\ oneindig \\ gelukkig een-saam draaiend
}


Die nimmer-eindigende siklus (O’Brien 1969:1-3, 237-251; Stokes 1971:153) wentel voort. Die volmaakte integrasie begin disintegreer. Die vier elemente maak hulself middelpunt-vlietend daaruit los, worstel om terug te keer tot die staat van vierheid, en slaag uiteindelik daarin:

Maar binne-in die saamstelling

het twis groot uitgegroei en die hoogste eer bestyg

en 'n tyd is vervul:

'n tyd van ruil

deur 'n breë eed vir hulle uitgemeet

Dit is duidelik dat die kosmos as geheel, en dus al die individuele dinge in die kosmos, hulle in een van twee prosesse bevind: óf van die staat van geskeidenheid van die oer-elemente op weg - vorentoe, maar ook terug - na hulle integrasie, óf van die staat van hul uiterste geïntegreerdheid terug - dit is ook vorentoe - na hulle volkome geskeidenheid.

In aansluiting by die gewone menslike denke en sentimente klink dit byna vanselfsprekend om die proses van geïntegreerdheid na gedisintegreerdheid te beskou as "dekadent". Dit is immers die proses van toenemende "twis". Maar in Empedokles se dinkraam is die teenoorgestelde net so waar: die proses van toenemende "liefde" is dekadent in die sin dat die oer-elemente gestroop word van hul selfgenoegsame uniekheid en opgeneem word in 'n grys moeras. Dekadensie is dus 'n ambivalente begrip. Net so sou die begrippe "ontwikkeling" en "vooruitgang" ambivalent en eintlik onbruikbaar wees. Hy poneer 'n ewige proses waarin daar geen oorspronklike begin en geen eskatologiese einde is nie.

In 'n sin is die leer van Empedokles eternalisties. Die vier wortelelemente - en dus die kosmos in die mees omvattende sin - is ewig, en opgeneem in 'n ewige proses. Anders gestel, liefde en twis en die vier elemente is goddelik. Al wat verander, is die onderlinge relasies van die wortels namate liefde of twis die bo-toon voer. Selfs in hul mees geïntegreerde staat word die integriteit van elkeen weliswaar gekompromitteer, maar nie volledig prysgegee nie. In fr 23 gebruik hy die beeld van 'n vaardige skilder wat 'n sekere oortuigende visuele effek oproep deur sy behendige gebruik van kleur. Hier moet nie gedink word aan 'n vermenging, byvoorbeeld in die sin dat rooi volledig met blou vermeng word om pers te bewerkstellig nie, maar in die sin dat vlekkies rooi en blou as 't ware pointillisties langs mekaar geplaas word om die visuele effek van pers te bereik. Elkeen van die 
vier wortel-"kleure" verloor weliswaar sy oorspronklike klaarheid as dit opgaan in die sintese van die skildery, maar die eie-aard van elkeen bly wesenlik ongeskonde.

Empedokles poneer 'n ewige tweeheid van eenheid en vierheid. Maar wat sit agter die dialektiek? Hier val Empedokles uiteindelik terug op één: 'n oerkrag (ananke) (fr 115) wat hy nie verder verduidelik nie maar slegs mitologies kan benader deur dit as 'n ewige godsbesluit (fr 115), 'n "eed" (fr 30) wat as 't ware kosmiese geregtigheid en balans handhaaf, voor te stel.

Waar in die proses verkeer die kosmos nou? Die mees waarskynlike rekonstruksie - ons moet onthou dat ons slegs 'n betreklik klein persentasie van die oorspronklike gedigte het, en dat die volgorde van die fragmente hipoteties is - is dat die kosmos tans op weg is na totale disintegrasie van die geheel (o a Millerd 1980:47-55; Wright 1981:195), aan die einde waarvan ook die einde van sterflikheid sal lê. Waar daar geen disintegrasie meer is nie, is ook geen sterflikheid en dood meer nie. Paradoksaal kom die totale disintegrasie van die één geheel neer op die totale integriteit van die vier. Lewende dinge kan op twee stadia voorkom. Op weg van volkome afsonderlikheid van die elemente (die veel, die vier) na volmaakte liefde (die een, die sfeer) kom afsonderlike ledemate (koppe sonder nekke, arms sonder skouers, oë sonder gesigte [fr 57]) tot stand, wat tot nog onvolkome geïntegreerde, hibridiese mitologiese monsterliggame verbind word, selfs tot mensesoorte; die huidige geslag mense het egter op weg van volkome liefde (die een, die sfeer) na volkome afsonderlikheid (die veel, die vier) ontstaan (Wright 1981:53-54, 206, 208, 211).

\subsection{Die menslike lewe}

Die groot siklus beheers nie slegs die makrokosmos nie, maar ook die mikrokosmos. Wesenlik is die mens in lewe en sterwe deel van die kosmiese, dit wil sê goddelike proses van liefde-en-stryd van die goddelike wortels.

Omgekeerd, gegewe hierdie wedersydse vervlegting, kan die ewige ritme van kosmiese verbinding en ontbinding soos Empedokles dit voorstel, gesien word as 'n ekstrapolasie van die biologiese, menslike ervaring van in- en uitasem, of van die sistool en diastool van die hart (Burnet 1955:73). Selfs in die staat van onbegrip is die mens deel van die goddelike proses. In daardie ewige sirkelgang neem die mens 'n besondere plek in: die mens misverstaan die groot proses; word meegesleur deur die behoefte aan liefde (veral die seksuele liefde waarvan Aphrodite die mitologiese simbool is); leef in 'n illusionêre werklikheid van veiligheid en gemak; word gepla deur konflik en stryd; en vrees die dood, wat ook deel van die illusionêre werklikheid is. 
Maar in die ontmoeting met 'n ware ("goddelike") leermeester wat self die ware insig verwerf en die ooreenstemmende lewenswyse verwerklik het ('n daimon), kan die leerling deurstoot na die dieper kennis en lewe. Wie deurgebreek het tot die ware kennis, het - stroom-op teen die drang van mense - insig in die staat van goddelike onsterflikheid bereik. Empedokles is selfbewustelik so 'n daimon, en praat in daardie hoedanigheid as leermeester met Pausanias.

Onsterflikheid beteken dat die mens (soos alle ander wesens) deel is van die ewige proses van samevoeging en skeiding van die onvernietigbare elemente. Empedokles se visie beklemtoon paradoksaal dat suiwer onsterflikheid afhanklik is van twis, stryd, ontbinding. "Dood" is 'n relatiewe saak, bloot ' $n$ tydelike ontbinding tussen 'n vorige en 'n volgende verbinding van die elemente in 'n nimmereindigende reeks van ver-binding, ont-binding en her-binding, van relatiewe "geboorte" en "dood":

$$
\begin{gathered}
\text { Nog iets sal ek sê: } \\
\text { van alle sterflike dinge } \\
\text { het nie een geboorte } \\
\text { of einde in aaklige dood nie } \\
\text { daar is net meng en skei van mengsel } \\
\text { mense noem dit "geboorte" }
\end{gathered}
$$

Agter die voorgrondskonvensies van "leef"en "sterf" is daar 'n ewige onsterflikheid:

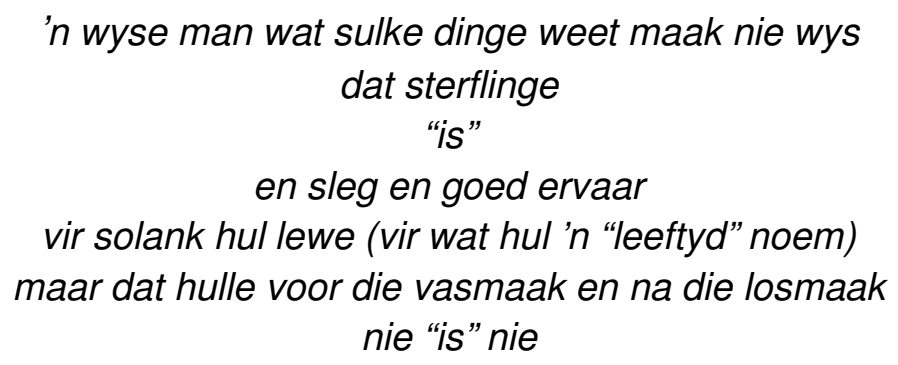

'n Noodwendige implikasie van hierdie ewige proses van her-"geboorte" en her-"sterf" is dat elke unieke mens-konstellasie kontinu is met vorige en volgende menslike en nie-menslike konstellasies: 
ek was al

seun en meisie

en bos en voël

en stil vis in die see

(fr 117)

Elkeen van die oer-wortels is onsterflik, maar Empedokles koppel die onsterflikheid van die god-mens, die "siel", die daimon, veral aan lug (aither) in sy ongekontamineerde oertoestand in die "oneindige hoogte" van die hemelruim.

Uit die verwantskap van alle vorme van lewe in die goddelike lewensproses van hergeboorte lei Empedokles (met sterk patos maar nie dwingende logika nie) af dat die slag, offer en eet van vleis verkeerd is inderdaad die afskuwelikste van alle misdrywe, niks anders nie as familiemoord en kannibalisme (Wright 1981:284):

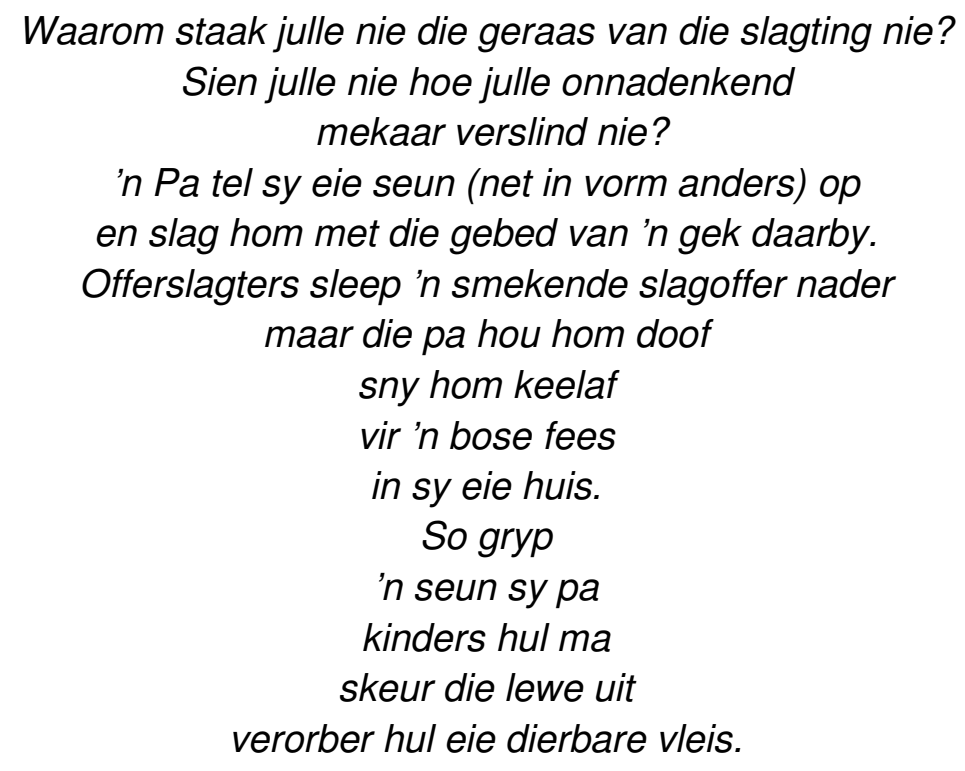

(fr 136-137)

Sy vegetarisme is deel van 'n wyer etiek van geweldloosheid. Sy betrokkenheid by die demokratiseringsproses in Akragas en sy sterk afwysende houding van die tirannie moet stellig ook in die wyer raam van sy metafisiese mistiek verstaan word. So ook sy sjamanistiese heling van mens en natuur (bv sy legendariese beïnvloeding van die weer). 


\section{HERKOMS}

Van vroeg af is daar veral twee kante aan Empedokles onderskei: die rasioneel-filosofiese, waarin hy voorgestel is as ' $n$ mede-grondlegger van die Europese rasioneel-wetenskaplik-filosofiese tradisie; en die misties-magiessjamanistiese. Hierdie twee kante sluit mekaar nie uit nie, en by Empedokles kom albei inderdaad voor (Dodds 1951:145-146 [wat hom as die laaste Griekse sjamaan sien]; Guthrie 1952:231-232). Die rekonstruksie van sy herkoms bring ons voor 'n komplekse situasie te staan waarvan die ontwarring nie ' $n$ eenvoudige saak is nie en wat penne vir meer as twee duisend jaar beweeg het. Die fenomeen "Empedokles" was 'n knooppunt van verskeie historiese drade wat oor eeue gestrek het, sy denke 'n saamgestelde mosaiek van affiniteite wat verskeie kultureel-religieuse kontekste omvat het. Die mees onlangse, omvattende, genuanseerde en oortuigende geheelbeeld tot dusver van die invloede waardeur Empedokles gekonstitueer is, is die van Kingsley (1995) wat ons nou hoofsaaklik volg - ten einde by 'n fassinerende grens en beperking van die huidige historiese ontwerpe (insluitend die van Kingsley 1995, 2003) uit te kom.

Biografies die naaste aan Empedokles lê Sisilië self as kulturele en religieuse entiteit: deel van Wes-Griekeland maar gewortel in 'n ouer, tipiesSisiliaanse en Suid-Italiaanse mitologie en magie-tradisie waarin die vulkaan Etna met sy suggestie van onder-aardse tonnels en ruimtes van vuur'n groot rol gespeel het. Die misteries en mitologie van voor-Griekse en Griekse Sisilië speel 'n onuitgesproke maar sterk rol in sy gedigte.

Verder terug in tyd en rondom in geografiese gebied strek die argaïese, wyd-verspreide sentraal- en noord-Asiatiese sjamanistiese tradisie (Eliade 1989) waaraan veral die Italiaanse Wes-Grieke deel gehad het danksy hul oorspronklike herkoms uit die Anatoliese (Klein-Asiatiese) kusstrook. Die Wes-Griekse stede het byna almal tot stand gekom as gevolg van migrasie vanuit daardie, aan Asië grensende, gebied. Die Griekse wêreld was nooit 'n afgeslote entiteit nie, maar wyd-oop na die noorde, ooste en suide ver rondom die Middellandse See. Griekeland was deel van die Mediterreense wêreld wat, afgesien van Klein-Asië en die Nabye Ooste, ook Afrika (Egipte, tot diep in die suide) ingesluit het. Vanuit Sisilië as middelpunt sou Empedokles die kultuur-religieuse trillings wat oor 'n lang tydperk oor 'n groot geografiese gebied met ' $n$ verskeidenheid kulture maar ook met groot kultuuroorspannende gemeenskaplikhede beweeg het, geregistreer het.

'n Meer Grieks-spesifieke kulturele laag bo-oor die argaïese sjamanisme wat ' $n$ vormende rol by Empedokles bly speel het, was die Homeriese literêre en mitologiese tradisie waarin hy gestaan het. In sy tyd was daardie tradisie in 'n proses van disintegrasie en terugdringing deur 
nuwer denke (waarvan Empedokles 'n verteenwoordiger was), maar dit was nietemin steeds die raamwerk waarbinne hy gedink het. Om te beweer dat hy "anti-mitologiserend" gedink het (Vollenhoven 1950:83) gaan te ver.

Empedokles was ook sterk geassosieer met die voor-Hellenistiese, esoteries-magiese Pythagorees-Orphiese beweging (Burkert 1985:276-304), in die konteks van die toenemende behoefte aan individuele verlossing, los van publieke, politieke religie. Die Orphisme, spekulerend oor die afdaal in en terugkeer uit die onderwêreld, het sterk wortels in Thrakië in die noord-ooste gehad, en was verbind met die sentraal- en noord-Asiatiese (Siberiese) sjamanistiese tradisie, wat oor Mesopotamiese, Iranese en Fenisiese brûe na die wêreld van Empedokles gelei het (Eliade 1982:180-209; Kingsley 1995:55, 226-227, 243, 331). Empedokles het direkte kontak gehad met die nawerking van die besonder invloedryke Pythagoras (c580-c500), wat self in die SuidItaliaanse en Sisiliaanse dampkring geleef het en Klein-Asiatiese en MiddeOosterse beïnvloeding in hom omgedra het. Die volgelinge van Pythagoras (Pythagoroi) het baie van hul aansienlike skat van werke - wat dikwels esoteriese inisiasies gedien het - aan Orpheus toegeskryf (West 1983:7-15). Empedokles was deel van daardie kaleidoskoop van gedagtes en praktyke, insluitend inisiasie-praktyke. Hy was 'n praktiserende magiër, opgeneem in 'n wye alchemiese, esoteries-magiese netwerk waarin historiese lyne van beïnvloeding kruis en dwars deur mekaar geloop het. Sy natuurkunde, waarvolgens die ganse goddelike kosmos met lewende kragte deurtrek was, was bedoel om 'n praktiese, helende toepassing te vind in die lewe van mens en breër natuur. Konneksies tussen Empedokles en die gnostiek is ook nie uitgesluit nie (Kingsley 1995:355; Kingsley 2003:324, 361, 383, 430-431).

Van sy filosofiese voorgangers in die sogenaamde "voor-Sokratiese" filosofiese tradisie het hy stellig, benewens Pythagoras, ook Herakleitos van verre Efese (c540 gebore) se werk geken. En hy was direk en sterk beïnvloed deur die metafisiese mistiek van Parmenides van Velia in Suid-Italië (c540 gebore), eweneens staande in die Pythagorese tradisie. Sy stelsel kan inderdaad voorgestel word as 'n poging om die nie-permanensie van Herakleitos en die eternalisme van Parmenides te versoen.

Oor bogenoemde beeld van die herkoms van Empedokles as geheel en oor onderdele daarvan kan en sal stellig nog baie in die voortgaande diskussies geskryf word. Die merkwaardige is egter - en dit is die grens waarop hierdie artikel wil wys - dat Kingsley (2003) nêrens na moontlike raakvlakke met die Indiese denke verwys nie, ten spyte daarvan dat sy vertolking van Empedokles verbasend "Boeddhisties" is. Ek het nie fout te vind met hierdie Empedokles-interpretasie as sodanig nie. Die probleem is egter dat dit nie duidelik word of Kingsley werklik-bestaande historiese 


\section{Die plek van Empedokles in die metafisies-mistieke tradisie}

korrelasies met Indië buite rekening laat, of vermoede historiese korrelasies (nog?) nie in die oopte (durf?) bring nie, of sulke historiese korrelasies van die hand wys nie. Waarop sy interpretasie (bedoeld of onbedoeld?) neerkom, is wat ek hierbo "tradisie-skepping" en "tradisie-konstruksie" genoem het. Ek beweer nie dat daar stellige bewyse van werklike historiese bande tussen die Griekeland en die Indië van daardie tyd was nie; wel, dat sulke verbande moontlik was. En ek meen dat van Kingsley verwag kon gewees het om sy resepsie- en interpretasieproses duideliker te gemaak het. Dieselfde geld van sy interpretasie van Parmenides (Kingsley 2003:15-306). Parmenides se affiniteit met die tydgenootlike Upanishadiese denke is net te groot om die waarnemer in die huidige uitbreidende kulturele en religieuse horison tevrede te laat voel met die gedagte van blote toevallige ooreenkomste. Die ooreenkomste moet deurlig word, indien nie histories nie, dan wel minstens teoreties, religie-filosofies, misties-metafisies. Slegs eenmaal verwys Kingsley na ooreenkomste tussen Empedokles en denkpatrone verder weg, as hy terloops "analogieë" met die Chinese denke konstateer (Kingsley 1995:298).

Hierdie historiese terughoudendheid kom nie slegs by Kingsley voor nie. Ewe merkwaardig bestudeer Scharfstein (1978:9-127; 1998) die filosofiese tradisies van die Nabye Ooste, Indië, China en die Weste langs mekaar en parallel met mekaar maar apart van mekaar, sonder enige poging om historiese oorvleueling, konvergensie en beïnvloeding te akkommodeer. Lambridis $(1976: 23,35,39,120,126,131)$ is net so versigtig in sy benadering, maar laat tog die moontlikheid van 'n Indiese, selfs Boeddhistiese konneksie, oop - maar poneer dan besonder onoortuigende ooreenkomste tussen Empedokles en die vroeë Boeddhisme (soos die identifikasie van die sphairos van volmaakte liefde met nirvana). Via die Klein-Asiatiese moederstede wat mengplekke van allerlei kulture en religieë was, kon Indiese invloede inderdaad in Italiaanse Griekeland werksaam gewees het. Maar agter die merkwaardige ooreenkomste tussen Griekeland en Indië het stellig ook 'n gemeenskaplike argaïese Indo-Europese oorlewering oor duisende jare, wat nie meer histories uitgeklaar kan word nie, gelê (Eliade 1982:190, 192, 371-374, 482-494).

'n Voorbeeld van 'n moontlike Indiese konneksie is Empedokles se leer van die vier elemente. Dit word algemeen aanvaar dat die vier elemente by Empedokles vir die eerste maal sistematies in die Griekse (Westerse) denke na vore getree het (sien bv Zeller 1963:949; Kingsley 1995:13). Gomperz (1896:447; gevolg deur Guthrie 1969:142) se terloopse stelling dat elementêre gedagtes oor hierdie vier basisstowwe toevallig en onafhanklik van mekaar in die Hindoeïstiese en Griekse volksfilosofieë ontstaan het, mag waar wees, maar dit verklaar nie die verbasende ooreenkomste in die twee 
stelle ontwikkelde misties-metafisiese denkbeelde aangaande die vier elemente volledig nie. In die vroeg-Boeddhistiese Satipatthāna Sutta byvoorbeeld word meditasie oor die vier materiële elemente aarde (dhātu), water (āpo), vuur (tejo) en lug/wind (vāyo) onderrig (Rhys Davids \& Carpenter $1911: 294)$ - en dit in 'n filosofies-deurdagte, esoteries-mistieke konteks wat sterk aan Empedokles herinner. So is die volgorde waarin die elemente genoem word, kennelik deurdag en dieselfde as by Empedokles. Die vroeë Boeddhisme lê in dieselfde epogale gleuf as Empedokles. Volgens die steeds mees aanvaarde kronologie het die Boeddha tussen 566 en 486 VHJ gelewe. Dit beteken dat Empedokles ongeveer tien jaar oud was toe die Boeddha gesterf het. Dit maak beïnvloeding van Empedokles deur die Boeddhisme 'n moontlikheid, maar nie noodwendig 'n sterk waarskynlikheid nie. Die sterk ekspansie van die Boeddhisme sou eers in die derde eeu VHJ ten tye van Asoka plaasvind. In elk geval het die vroeë Boeddhisme in hierdie (soos ook in ander) opsigte ouer Indiese denkbeelde voortgesit. Die denkbeeld van hierdie vier elemente het 'n lang geskiedenis in die Indiese natuurfilosofie. Dit gaan terug op die eerste laag van Indiese filosofie, naamlik die tydperk van die Vediese proto-filosofie (Frauwallner 1973a:27-75) en het reeds in die Vaisesika-Sutra van Kanāda (waarskynlik sewende of sesde eeu VHJ) 'n filosofiese vorm gehad (Dasgupta 1963:285-288; Frauwallner 1973b:14-15, 17, 22-25, 84-86). Net soos by die Boeddhisme en Empedokles later, was die Vaisesika-natuurkunde met die leer van die vier materiële substansies (dravya) ingebed in 'n soteriologiese konteks (Dasgupta 1963:285).

Die strekking van die argument dat daar onbekende historiese verbande tussen Empedokles en die Indiese denke (spesifiek nou wat betref die vier elemente) bestaan, beteken nie 'n onderwaardering van die skeppende oorspronklikheid van Empedokles nie. 'n Vergelyking van die beskikbare materiaal toon die geniale uniekheid van Empedokles se visie.

Kortom, die Asiatiese hinterland van die Griekeland van die vyfde eeu het waarskynlik tot in Indië - dus verder as wat in die bestaande Empedoklesliteratuur erken word - gestrek. In daardie groter poel van Asiaties-Indiese en Europees-Mediterreense kultuur en religie kon, afgesien van agtergrondbepaalde oreenkomste, ook direkte ontlenings plaasgevind het. In sulke gevalle sou filosofiese idees waarskynlik eerder van die ouer Indiese tradisie af na Griekeland toe as andersom getrek het. Sulke invloede kon Empedokles direk, of deur die bemiddeling van veral die Pythagorese beweging bereik het. Maar op hierdie stadium kan die tergende moontlikheid van beïnvloeding uit Indië waarskynlik nie histories opgelos word nie.

Die mate waarin Kingsley Empedokles "Indies"-"Boeddhisties" interpreteer sonder om dit hermeneuties of histories-krities te ekspliseer, is 
opvallend. In verskeie kontekste (bv Kingsley 2003:330-341, 368-370, 384399, 401-406, 415-429, 432-441, 446-460) interpreteer hy metis (wat in fragmente 2, 23 en 106 voorkom) en Empedokles se benadering tot ware wete in die algemeen op maniere wat enersyds die betekenis van die oorspronklike tekste skyn te rek, en andersyds verbasend naby aan IndiesBoeddhistiese begrippe soos sati (aandag) en upāya (vindingrykheid) (Pye 1978) en Indies-Boeddhistiese meditasie-praktyke skyn te kom. Onkunde by Empedokles herinner sterk aan die Indies-Boeddhistiese onkunde. Die wêreld van die oppervlakkige ervaring is 'n illusie. Aandagtigheid ("awareness", "alertness") in 'n meditatiewe konteks is nodig. Vergelyk byvoorbeeld die volgende sin: "And only one factor can help us now. This is the razor-sharp awareness, the totally focused sensitivity to the present moment, known to the Greeks as metis" (Kingsley 2003:454). Daarby kom nog dat metis by Kingsley die betekenis van "resourcefulness", "cunning", "trickery", "deception" ontvang op 'n manier wat dit verbasend naby aan die Mahayana-beeld van die vindingryke bodhisattva soos dit byvoorbeeld in die Lotus sutra (Watson 1993) geskilder word, bring. Empedokles praat in raaisels, al konformeer hy oppervlakkig aan konvensie. Hy pas by by ons dink-en spreekgewoontes aan, daal tot ons vlak af, is 'n meester van vermomming, weerkaats onsself, ten einde ons met vaardigheid in die esoteriese waarheid in te lei, aldus Kingsley. Dit sou natuurlik geldig wees om te argumenteer dat die Boeddhisme self 'n veel ouer, sjamanistiese tradisie voortsit (Eliade 1989), maar selfs dan sou die opvallende ooreenskomste tussen Empedokles en die Indies-Boeddhistiese benadering van destyds (en vandag) om 'n nadere verduideliking vra. Bogenoemde is nie al nie. In Kingsley se uiteensetting is ware kennis direkte ervaring, en lyk die leermeester baie soos ' $n$ guru. Die leermeester maak gebruik van die beginsel van kontradiksie/inversie en saboteer ons kennis van binne af op ' $n$ wyse wat inderdaad baie aan Nagarjuna herinner. Net so ook die toeken van name in die konvensionele kennis-konteks, wat eintlik selfbedrog is. Die leermeester lei - ons bly nog steeds in die kielwater van Kingsley se uiteensetting - sy aandagtige dissipel tot by 'n punt anderkant die rede, waar al sy objektiwiteit en sy gesonde verstand in duie stort.

Soortgelyk aan die vroeë Boeddhisme is ook dat Empedokles volgens Kingsley (2003:356-357, 377-379, 392-395, 400-402, ens) nie "liefde" (philotes) bo "haat" (neikos) plaas nie, maar 'n ruimte van dieper insig anderkant albei opsoek.

Ander raakpunte wat om verdere vergelykende analise vra, is die volgende: 
a) Die vergelykbare rolle van ananke en karma as waarskynlik die mees basiese enkele drywende krag in die onderskeie twee ontologieë.

b) Die feit dat die Boeddha en Empedokles kennelik op dieselfde stadium van afskeid-neem van die ou Vediese en Homeriese religieuse mitologieë was: naby genoeg om hulle nie direk te ontken nie, maar ver genoeg om hulle indirek - maar radikaal - te problematiseer.

c) Die verwantskap tussen die denke van Empedokles oor die disintegrasie van dinge en die Boeddhistiese "leegheid". In die taal van Kingsley (2003:407-408): in die stroom-op swem teen die vloei van die konvensionele lewe "[W]hatever gives a sense of fulfilment becomes emptiness". Kingsley (2003:418-421, 430-433 ens) se interpretasie van stryd as die beginsel van disintegrasie herinner aan die Boeddhistiese ekwivalent van disintegrasie, genoem anicca (nie-permanensie), anatta ("self"-loosheid), paticcasamuppāda ("afhanklike mede-totstandkoming") van alle saamgestelde dinge. Soos by die vroeë Boeddhisme, so is die totale disintegrasie van alle dinge by Empedokles paradoksaal die einde van sterflikheid. Die dieper wete van die nie-ewige saamgesteldheid van alle dinge bring die einde van die dood mee.

d) Die daimon van Empedokles herinner sterk aan die Boeddhistiese bodhisatva-, miskien selfs buddha-begrip.

Die verskille tussen die twee stelsels is ewe opvallend. 'n Interessante vergelykingspunt met spesifiek die Boeddhisme is byvoorbeeld die relasie tussen liefde en twis (haat). By die vroeë Boeddhisme draai die konvensionele mikro-kosmiese (menslike) lewensproses om die drie ongesonde "wortels" (mula) van onkunde (avijjā), aantrekking (tanha, rāga, lobha, met spesifieke insluiting van seksuele aantrekking) en afstoting (dosa). Maar liefde en stryd wat by die onspekulatiewe vroeë Boeddhisme psigologiese toestande is, word by Empedokles makro-kosmiese kragte. Dit is 'n sterk verskil tussen die twee stelsels.

Wat die vier elemente betref: terwyl hierdie denkbeeld in die vroeë Boeddhisme (Rhys \& Carpenter 1911:294) in 'n meditatiewe konteks, op kalmte en mistieke insig gerig, funksioneer, lyk dit asof dit by Empedokles bloot 'n natuurkundige (chemiese) funksie het. Maar hier moet ons in gedagte hou dat ons nie die hele oeuvre van Empedokles tot ons beskikking het nie. Wie weet wat verlore gegaan het? Anders as die vroeë Boeddhisme praat 
Empedokles van die onsterflikheid van die goddelike beginsel (daimon) in die mens (Kingsley 2003:358-367, 430) - maar hier trek hy Empedokles ver in die rigting van die gnostiek.

\section{NAKOMS}

Hoe beroemd Empedokles ook al tydens sy leeftyd in Griekeland was, het hy geen eie skool nagelaat soos Pythagoras gedoen het nie. Tog het hy op die esoteries-mistieke terrein 'n beduidende nawerking gehad, ook in die wye web van die latere Pythagorisme wat in die volgende paar eeue wisselwerkend met die breër Grieks-Egiptiese alchemie, magie en hermetisisme verband gehou het (Kingsley 1995:332-334).

Soos algemeen aanvaar word, het Empedokles 'n groot bydrae gemaak tot die begronding van Westerse wetenskaplike dissiplines soos die filosofie, retoriek, medisyne, kosmologie, astronomie en natuurlik chemie. Hy funksioneer by Plato wat hom, soos hy dikwels met skrywers voor hom gedoen het, vir sy eie doeleindes aangepas het. In die antieke Griekse filosofie het veral Aristoteles en sy leerling Theophrastus Empedokles aan streng filosofiese toetsing onderwerp, waarin Aristoteles sy ongeduld met wat hy as Empedokles se filosofiese inkonsekwenthede beskou het, nie verberg het nie. Tog het hy hom ernstig opgeneem, en geen denker behalwe Plato met soveel aandag behandel nie. Hy het Empedokles waarskynlik as die betekenisvolste voor-Sokratiese filosoof beskou (O'Brien 1969:72 e v).

Die misties-sjamanistiese kant aan Empedokles is nooit ontken nie. Maar namate die rasionele element in die Westerse kultuur (inderdaad grotendeels onder invloed van Aristoteles) toegeneem het, is daardie kant van Empedokles toenemend negatief beoordeel. Dit was reeds by Aristoteles, wat die poëties-mitiese elemente in Empedokles nie kon verdra nie, die geval. In die mate dat hy digter was, was hy mislukte filosoof. Terwyl sy aandele in die Westerse filosofiese tradisie nie hoog gebly het nie, het 'n merkwaardige ontvangs Empedokles te beurt geval in Hellenistiese en post-Hellenistiese Egiptiese Islam, in 'n esoteriese konteks wat met gnostiese, hermetiese en Platoniese idees deurtrek was (Kingsley 1995:55-68, 221, 233-249, 298-299, 371-391, 395). En in die twaalfde eeu het die Persiese mistikus al-Suhrawardi Empedokles as 'n sufi-meester voorgestel (Kingsley 1995:381). Langs sulke half-ondergrondse weë het Empedokles deur die Middeleeue bly nawerk, om in die Renaissance weer meer prominent te word. In die Middeleeue het die dramatiese Sisiliaans-Suid-Italiaanse mitologie van onderaardse vuur (waarvan Empedokles ' $n$ draer was), in Joodse, Christelike en Moslemvoorstellings van die vurige hel onder die aarde nageklink, byvoorbeeld buitengewoon sterk in Dante se voorstelling van Inferno. Die Renaissance- 
tydperk het, in die konteks van die kritiek op die eensydige klem op die rasionele dimensie van die menslike bestaan en die herontdekking van die Westerse hermetiese tradisie, 'n nuwe waardering vir Empedokles as mistieke denker meegebring. So byvoorbeeld het Giordano Bruno hom met die aanvang van die moderne epog op Empedokles beroep vir sy postulaat van 'n wêreldsiel (anima del mondo) en universele, kosmiese intellek (intelletto universale) (Bruno 1985:231-232). Sonder om na Empedokles te verwys, het niemand ooit so na aan Empedokles as tipe van die esoteriese geneser gekom nie as die Renaissance-figuur Paracelsus.

In die moderne tyd was dit veral Friedrich Hölderlin wat in sy onvoltooide drama Hyperion Empedokles buitengewoon ernstig opgeneem en in die konteks van die Duitse Idealisme aansluiting by sy natuurmistiek gesoek het (Foti 1999:278-287). In die huidige Westerse filosofiese beoordeling word (hoofsaaklik onder die invloed van Nietzsche en Heidegger) Anaximander, Heraklitus en Parmenides oorwegend as die drie grootste pioniersfigure beskou. Mens sou kon vermoed dat Nietzsche, op grond van wat hy self die "tragiese element" van Empedokles noem (Nietzsche 2001:113) 'n sterk affiniteit met Empedokles sou gehad het. Ander merkwaardige ooreenkomste (soos die tema van die ewige terugkeer en Nietzsche se verstaan van daardie Griek as wesenlik grensfiguur: digter en retorikus, god en mens, wetenskaplike en kunstenaar) (Nietzsche 2001:119) sou hierdie verwagting versterk. Nietzsche bly egter verrassend terughoudend. By Heidegger speel Empedokles eintlik geen rol nie (Foti 1999:277-294).

\section{TOEKOMS}

Watter waardering kom Empedokles toe en wat sou sy toekoms wees in die raam van die ontmoeting van die verskeie en skynbaar uiteenlopende mistieke tradisies in die raamwerk van die kultureel-religieuse situasie van vandag?

Op die veronderstellings van hierdie artikel verskyn Empedokles nie as 'n naïewe, na filosofie tastende "voor-Sokratiese" figuur nie, maar - met volle inagneming van historiese verskille tussen toe en nou - as 'n betekenisvolle gespreksgenoot in een eeue-omspannende debat. Nou dat die moderne Westerse vooroordeel ten gunste van rasionaliteit aan sterk druk onderwerp word, kan weer na hom geluister word met dieselfde oop, vraende gemoed as na Jesaja en Jeremia, Plato en Plotinus, die Upanishads en die Boeddha. Hy is 'n eksponent van 'n sintese van rede-en-wetenskap en mistieke intuïsie wat in ons dag, onder ander maar vergelykbare kulturele voorwaardes, in verskeie kringe opnuut waardeer word. Sy volgehoue poging om skeppend in die 


\section{Die plek van Empedokles in die metafisies-mistieke tradisie}

spanningsveld tussen rede, mitologie en mistiek te beweeg, is vandag nog die uitdaging vir diegene wat op die grense van die dink- en sêbare beweeg. So lank as daar mense is, sal sy poging om sy tydgenote deur onderrig en die beoefening van 'n mistieke dissipline tot 'n dieper wete te lei, relevant bly. Dit is die soort ding wat tot by die heel begin, tot op die been en in die murg van menswees teruggaan, waaraan 'n paar eeue van veranderende sosiale omstandighede geen wesenlike verskil maak nie.

Saam met sy voorgangers en tydgenote loënstraf hierdie digter-denker die holruggeryde stelling dat "die Weste" as 't ware inherent "rasionalisties" en "materialisties" sou wees, en herinner hy aan die indrukwekkende mistieke tradisie wat aan die wortel van die Westerse beskawing lê. Sy kenteorie lê in die vroeë stadium van die lyn wat later in die Neoplatonisme tot 'n grootse mistieke stelsel sou ontwikkel. Die Neoplatonisme weer sou in 'n groot mate die teoretiese matrys van die Christelike mistiek en van groot dele van die Joodse en Moslem-mistiek vorm. Deur historiese bande en strukturele affiniteite oorvleuel sy denke in 'n groot mate met vorme van Indiese denke wat gedurende die afgelope eeu en 'n half die Weste sou verower. Dit sou ten dele gebeur omdat die ou en ryk Westerse mistieke tradisie in die Westerse bewussyn self in 'n groot mate verdring en vergete was.

Empedokles se visie van die ewige spanning tussen liefde en twis en van die generatiewe krag van twis bevat ' $n$ tydlose tragiese element wat hom nie net in die buurt van sy ouer tydgenoot Aeschylus plaas nie, maar ook van die sewentiende-eeuse skoenmaker-mistikus, Jacob Böhme, en van die negentiende-eeuse Friedrich Nietzsche. Sy intuïsie van die ewige kringloop van dinge gee uitdrukking aan 'n baie ou metafisies-mistieke denkrigting wat oor millennia veral in Indië op 'n grootse wyse ontwikkel is, en vandag nog net so ' $n$ lewende tradisie is as twee en ' $n$ half duisend jaar gelede. Aan fronte van die hedendaagse natuurwetenskap is daar 'n merkwaardige openheid om die gedagte van 'n lewende heelal ernstig op te neem, soortgelyk aan die manier waarop Empedokles dit uitgedruk het. Die rigting waarin hy getas het wat betref die lewe en dood van die individuele mens (reïnkarnasie) en die etiese gevolgtrekkings wat hy daaruit gemaak het (o a vegetarisme), is vandag nog vir miljoene mense 'n lewende veronderstelling en lewensreël. Net so bly dit die moeite werd om kennis te neem van sy demokratiese sentiment, wat eweneens met die basiese impulse van sy visie saamhang, byvoorbeeld dat die mens deel het aan die goddelike, makro-kosmiese natuur. Ekologies relevant is sy siening dat mens en bos en voël en stil vis in die see wesenlik verwant is en opgeneem is in een en dieselfde sirkelgang van lewe. En interessant met die oog op die huidige debat aangaande die gelykheid van die manlike en vroulike genders is die implikasie van sy siening 
van reïnkarnasie (ek was al seun en meisie). Alles in ag genome, is Empedokles, vandag 'n betreklik onbekende figuur uit die vroeë Westerse mistiek-geskiedenis, 'n groot en boeiende denker van 'n formaat wat hom oor die eeue veelseggend met ons laat kommunikeer in die wordende tradisie van 'n uitbreidende al-menslike gespreksruimte.

\section{Literatuurverwysings}

Bruno, G 1985. Dialoghi Italiani I: Dialoghi metafisici. Firenze: Sansoni.

Burnet, J [1914] 1955. Greek philosophy, Part I: Thales to Plato. London: Macmillan. Burkert, W [1977] 1985. Greek religion: Archaic and classical. Oxford: Blackwell.

Dasgupta, S [1922] 1963. A history of Indian philosophy, vol I. Cambridge: Cambridge University Press.

Diels, H (Herausg Walther Kranz) [1903] 1992. Die Fragmente der Vorsokratiker: Griechisch und Deutsch. Zürich: Weidmann.

Dodds, E R 1951. The Greeks and the irrational. Berkely, CA: University of California Press.

Dreyer, P S 1976. Die wysbegeerte van die Grieke. Pretoria: HAUM.

Eliade, M 1978. A history of religious ideas, vol 1. From the Stone Age to the Eleusinian Mysteries. Chicago, IL: Chicago University Press.

Eliade, M 1982. A history of religious ideas, vol 2. From Gautama Buddha to the triumph of Christianity. Chicago, IL: Chicago University Press.

Eliade, M 1989. Shamanism: Archaic techniques of ecstacy. London: Arkana.

Foti, V 1999. Empedocles and tragic thought: Heidegger, Hölderlin, Nietzsche, in D C Jacobs (ed), The Presocratics after Heidegger, 277-294. New York: State University of New York Press.

Frauwallner, E 1973a. History of Indian philosophy, vol I. Delhi: Motilal Banarsidass.

Frauwallner, E 1973b. History of Indian philosophy, vol II. Delhi: Motilal Banarsidass.

Gomperz, T 1896. Griechische Denker: Eine Geschichte der antiken Philosophie, Erster Band. Leipzig: Verlag Von Veit.

Guthrie, W K C [1952] 1993. Orpheus and Greek religion. Princeton, NJ: Princeton University Press.

Guthrie, W K C 1969. A history of Greek philosophy, vol II. The Presocratic tradition from Parmenides to Democritus. Cambridge: Cambridge University Press.

Kingsley, P 1995. Ancient philosophy, mystery and magic: Empedocles and Pythagorean tradition. Oxford: Oxford University Press.

Kingsley, P 2003. Reality. Inverness, CA: Golden Sufi Centre.

Kirk, G S \& J E Raven 1966. The presocratic philosophers: A critical history with a selection of texts. Cambridge: Cambridge University Press.

Krüger, J S 2006. Sounding unsound: Orientation into mysticism. Pretoria: Aurora.

Lambridis, H 1976. Empedocles: A philosophical investigation. Alabama, AL: University of Alabama Press.

Millerd, C E [1908] 1980. On the interpretation of Empedocles. London: Garland Publishing.

Nietzsche, F 2001. The Pre-Platonic philosophers, translated from the German and edited, with an introduction and commentary by Greg Whitlock. Chicago, IL: University of Illinois Press. 
O'Brien, D 1969. Empedocles' cosmic cycle: A reconstruction from the fragments and secondary sources. Cambridge: Cambridge University Press.

Pye, M 1978. Skilful means: A concept in Mahayana Buddhism. London: Duckworth.

Rhys D T W \& Carpenter, J E 1911. The Digha Nikaya, vol 1. London: Pali Text Society.

Scharfstein, B-A 1978. Philosophy East/Philosophy West: A critical comparison of Indian, Chinese, Islamic, and European philosophy. Oxford: Oxford University Press.

Scharfstein, B-A 1998. A comparative history of world philosophy from the Upanishads to Kant. New York: State University Press.

Stokes, M C 1971. One and many in presocratic philosophy. Washington, DC: Center for Hellenic Studies.

Vollenhoven, D H Th 1950. Geschiedenis der wijsbegeerte, Eerste band. Inleiding in de geschiedenis der Grieksche wijsbegeerte vóór Platoon en Aristoteles. Franeker: Wever.

Watson, B (tr) 1993. The Lotus sutra. New York: Columbia University Press.

West, M L 1983. The Orphic poems. Oxford: Clarendon.

Wright, M R 1981. Empedocles: The extant fragments, edited with an introduction, commentary, and concordance. New Haven: Yale University Press.

Zeller, E 1963. Die Philosophie der Griechen in ihrer geschichtliche Entwicklung, Erster Teil, zweite Abteilung. Allgemeine Einleitung. Vorsokratische Philosophie. Hildesheim: Georg Olms Verlag. 